\title{
Child mortality for avoidable causes in Rondônia: temporal series study, 2008-2018
}

\author{
Mortalidade infantil por causas evitáveis em Rondônia: \\ estudo de série temporal, 2008-2018
}

Mortalidad infantil por causas evitables en Rondônia: estudio serie temporal, 2008-2018

\section{Jeanne Lúcia Gadelha Freitas ${ }^{a}$ Jéssica Cunha Alves \\ Priscilla Perez da Silva Pereira ${ }^{a}$ \\ Kátia Fernanda Alves Moreira ${ }^{a}$ \\ Edson dos Santos Farias ${ }^{\mathrm{a}}$ Daniela Ferreira Borba Cavalcante ${ }^{a}$}

How to cite this article:

Freitas JLG, Alves JC, Pereira PPS, Moreira KFA, Farias ES, Cavalcante DFB. Child mortality for avoidable causes in Rondônia: temporal series study, 2008-2018. Rev Gaúcha Enferm. 2021;42:e20200297. doi: https://doi.org/10.1590/19831447.2021.20200297 a Fundação Universidade Federal de Rondônia (UNIR), Centro de Ensino e Pesquisa em Saúde Coletiva. Porto Velho, Rondônia, Brasil.

\section{ABSTRACT}

Objective: To investigate the trend of infant mortality from preventable causes in children under one year of age in Rondônia from 2008 to 2018

Method: Epidemiological study of time series with data from the Mortality and Live Birth Information Systems, driven by STATA ${ }^{\oplus}$ version 11.0, trend measured by Prais-Winsten linear regression and autocorrelation with Durbin and Watson test.

Results: The infant mortality rate was 14.57 deaths / 1,000 live births, 9.14 / 1,000 due to preventable causes. Deaths decreased by $2.88 \%$ annually (95\% Cl: - 4.67; -1.06). However, causes that can be reduced by running immunization actions, to women during pregnancy and fetal and non-childbirth growth, have stable rates. Deaths from preventable causes in the late neonatal period were declining (-11.69\%; 95\% (l-19.56;-3.05).

Conclusion: Managers need to qualify maternal and child care, considering the performance of the team of professionals in assisting the pregnant-puerperal cycle as well as improving the quality of infant mortality records in the region.

Keywords: Infant mortality. Child. Cause of death.

\section{RESUMO}

Objetivo: Investigar a tendência da mortalidade infantil por causas evitáveis em crianças menores de um ano em Rondônia de 2008 a 2018.

Método: Estudo epidemiológico de série temporal com dados dos sistemas de Informação sobre Mortalidade e sobre Nascidos Vivos, analisados pelo STATA ${ }^{\oplus}$ versão 11.0, tendência aferida por regressão linear de Prais-Winsten e autocorrelação com teste de Durbin e Watson.

Resultados: A taxa de mortalidade infantil foi de 14,57 óbitos/1.000 nascidos vivos,9,14/1.000 por causas evitáveis. Óbitos tiveram decréscimo anual de 2,88\% (IC95\%:-4,67; -1,06). Entretanto, causas reduzíveis por ações adequadas de imunização, à mulher na gestação e crescimento fetal e no parto, tiveram taxas estáveis. Óbitos por causas evitáveis no período neonatal tardio estiveram em declínio (-11,69\%; |C95\%-19, 56;-3,05).

Conclusão: Gestores precisam qualificar o cuidado materno-infantil, considerando a atuação da equipe de profissionais na assistência ao ciclo gravídico-puerperal bem como melhorar a qualidade dos registros de mortalidade infantil na região.

Palavras-chave: Mortalidade infantil. Criança. Causas de morte.

\section{RESUMEN}

Objetivo: Investigar la tendencia de la mortalidad infantil por causas prevenibles en menores de un año en Rondônia de 2008 a 2018. Método: Estudio epidemiológico de series de tiempo con datos de los Sistemas de Información de Mortalidad y Nacidos Vivos, impulsado por STATA ${ }^{\oplus}$ versión 11.0, tendencia medida por regresión lineal de Prais-Winsten y autocorrelación con la prueba de Durbin y Watson. Resultados: La tasa de mortalidad infantil fue de 14,57 defunciones / 1.000 nacidos vivos,9,14 / 1.000 por causas prevenibles. Las muertes disminuyeron en un 2,88\% anual (IC del 95\%: -4,67; -1,06). Sin embargo, las causas que pueden reducirse ejecutando acciones de inmunización, a las mujeres durante el embarazo y el crecimiento fetal y no durante el parto, tienen tasas estables. Las muertes por causas prevenibles en el período neonatal tardío estaban disminuyendo (-11,69\%; IC del 95\% -19,56;-3,05).

Conclusión: Es necesario que los gestores califiquen la atención materno-infantil, considerando el desempeño del equipo de profesionales en la atención al ciclo gestante-puerperal y mejorando la calidad de los registros de mortalidad infantil en la región.

Palabras clave: Mortalidad infantil. Niño. Causas de muerte. 


\section{口INTRODUCTION}

Infant Mortality (IM) consists of the death of children in their first year of life. It is common knowledge that precarious socioeconomic conditions, difficulties in accessing essential services, low quality of prenatal care and perinatal diseases are among the main causes of childhood deaths that impact on variations in the infant mortality rate (IMT) ${ }^{(1-2)}$.

Infant mortality has become a universal health indicator that, combined with biological, demographic, sociocultural, socioeconomic and educational factors, reveals the quality of care provided to children. This indicator partly reflects the failures and gaps in maternal and child health care at different levels(1). Reducing IM until 2030 is a worldwide challenge for this millennium. The impact expected is a reduction in preventable neonatal deaths to 12 per thousand live births and children under five to 25 thousand live births ${ }^{(3)}$.

Globally, in 2018, about 5.3 million deaths of children up to 15 years of age occurred in the first five years of life due to preventable causes. Of these deaths, $47 \%$ occurred in the neonatal period, and 29\% between one and 11 months of life. That same year, the worldwide neonatal mortality rate dropped to 17.19 per 1,000 live births (LB), while post-neonatal mortality fell to $11 / 1,000$ LB. Even so, $80 \%$ of newborn deaths would have been prevented with basic care ${ }^{(3-4)}$.

According to the United Nations Children's Fund (UNICEF), IM rates vary according to the level of socioeconomic and cultural development of the population. In low-income countries, the average neonatal mortality is between $27 / 1,000 \mathrm{LB}$ whereas high-income countries exhibit a rate of only $3 / 1,000$ LB. Countries such as Singapore and Japan, for example, had the lowest IMR in 2018 (2/1,000 live births). On the other hand, Afghanistan presented a rate of 109/deaths per 1,000 born in the same period ${ }^{(3)}$.

In Brazil, the adoption of maternal and child-care policies has contributed to the gradual reduction of the IMR over the decades ${ }^{(2)}$. Only in the last 15 years has the IMR dropped from 29.02 to $13.82 / 1,000$ live births ${ }^{(5)}$. In the post-neonatal component, there was a significant decline in IMR, especially between 1990-2012, with a reduction from 47.1 to 14.6 deaths $/ 1,000 \mathrm{LB}$, with more than half taking place in the early neonatal period ${ }^{(6)}$. Regarding IMR by preventable causes, there was a significant change in this indicator between 2006 and 2012, with a reduction from 11.6 to 9.3 deaths/1,000 live births in different regions of the country ${ }^{(7)}$.

Demographic changes such as reducing fertility in young women, improving living conditions, increasing schooling, implementing strategies such as vaccination and encouraging breastfeeding as well as implementing the Rede Cegonha - a strategy within the scope of SUS that covers the access to reproductive planning and humanized care during pregnancy, childbirth and the puerperium ${ }^{(7-8)}$ - all contributed to this scenario.

Despite these considerable advances in the fight against IM in the country, most infant deaths are preventable, therefore, sensitive to actions in the Unified Health System (SUS) network ${ }^{(8)}$. Obstacles such as the disconnection between prenatal and childbirth services, poor distribution of obstetric beds and the absence and low quality of health actions contribute to high $\mathrm{IMR}^{(2)}$.

In the northern region of Brazil, the average IM rate in recent years was high until 2016 with 17.6 deaths/1,000 LB. States such as Amapá (23.2 deaths/1,000 LB) and Rondônia (20.0 deaths $/ 1,000$ LB) had higher rates than those of the country $(13.3 / 1,000 \mathrm{LB})$ in the same year ${ }^{(5,9)}$. They are indicators with a strong influence, for example, of high death rates in indigenous children (50.0/1,000 LB), especially in the North and Center-West regions ${ }^{(10)}$.

At a local level, a study that analyzed infant mortality in the capital of Rondônia from 2006 to 2010, identified the association of infant deaths from preventable causes with failures in prenatal, delivery and newborn care. In that study, the IMR was 21/1,000 LB, higher than that of Brazil (15.7/1,000 LB) in the same period ${ }^{(11)}$. Another analysis by the same authors, in the same municipality, in later years (2011-2015) showed an average reduction in IMR of 9.23 deaths/1000 LB, especially in the early neonatal component ${ }^{(12)}$. In 2008, the IMR in the region was 21.7 deaths per 1,000 live births and the proportional mortality by age in children up to one year old, was 50.69 among newborns from zero to six days, 15.60 deaths for seven to 27 days and 33.72 for newborns aged over 28 days up to one year of age. In 2017, the chance (\%) of a child not reaching the age of 1 year of age was 19.6\% against the national average $(12.8 \%)^{(13)}$.

Considering this evidence, this is justified due to the fact that it considers the gap in the knowledge on the causes and tendency of IMR by preventable causes in the entire state of Rondônia. The unprecedented mapping of this information is crucial to understand the health-disease process in this group, aiming at planning strategies to prevent hospitalizations for conditions sensitive to primary care (ICSAP) and, consequently, the reduction of IMR ${ }^{(14)}$.

In addition, the guidelines of the National Policy for Comprehensive Child Health Care (PNAISC) instituted under the SUS since 2015, recommends, among other actions, the monitoring and evaluation of indicators to reduce child morbidity and mortality ${ }^{(15)}$.

Given the above, this study aimed to investigate the trend of Infant Mortality (IM) in children under one year of age in the state of Rondônia, between 2008 to 2018. 


\section{METHOD}

Epidemiological time series study, based on secondary data from the Mortality Information System (SIM) and Live Birth Information System (SINASC), available at the SUS Computer Information Department (DATASUS) from January 2008 to December 2018. Census data and population estimates from the Brazilian Institute of Geography and Statistics (IBGE) were also used. Data collection, extraction and analysis took place between January and April of 2019.

The State of Rondônia is located in the North of the country, has 52 municipalities and, in 2019, it had 1,777,225 inhabitants. Of that total, $8.18 \%$ were children under four years old. The per capita household monthly income of the resident population was BRL 1,136.00, the Human Development Index (HDI) was 0.690, ranking 15th in the national ranking and the illiteracy rate was $8.1 \%$ for people over 15 years $^{(16)}$.

The causes of death were classified as preventable and not preventable, considering the outcome by SUS interventions ${ }^{(17)}$ and groups of causes that can be reduced by appropriate actions, according to the criteria of the Brazilian List of Causes of Avoidable Deaths (Chart 1).

The data was also organized into two components: 1) neonatal mortality - deaths from 0 to 27 days of life; 2 ) post-neonatal - 28 days to a year divided into early - zero to six full days of life and late neonatal component - seven to 27 days of life (7). $^{(7)}$

Descriptive analyzes were performed expressed in absolute and relative frequencies. The proportional mortality rates by type of classification that are not preventable and those that are preventable, and subsequently by group of causes reducible by actions considered appropriate for the mother or newborn, were calculated using the total number of deaths by type in the specific year, divided by the total population of interest, in the same area and year, multiplied by 1,000 .

For trend analysis, defined as stationary, decreasing or increasing, linear regression was performed using the Prais-Winsten technique, after verification of serial autocorrelation using the Durbin and Watson test. The annual trend of the mortality rate by component was presented with the 95\% Confidence Interval (95\% Cl). The data were analyzed using the Stata ${ }^{\circledR}$ software version 11.

The study is linked to the matrix project "Study on morbidities in Rondônia," of the Center for Studies and Research in Public Health (CEPESCO). The research complied with Resolution 466/12(18) approved by the Research Ethics Committee of the Federal University of Rondônia, authorized by opinion No.2,548,115.

\begin{tabular}{|c|c|}
\hline \multirow{6}{*}{ Avoidable causes } & 1. Causes reducible by immunization and sensitive conditions \\
\hline & 2. Causes reducible by appropriate actions for women during pregnancy and fetal growth \\
\hline & 3. Causes reducible by appropriate actions for women during childbirth \\
\hline & 4. Causes reducible by appropriate actions for the newborn \\
\hline & 5. Causes reducible by adequate prevention, diagnosis and early treatment \\
\hline & 6. Causes reducible by appropriate Health Care and Promotion actions \\
\hline
\end{tabular}

Chart 1 - Classification of infant death according to the Brazilian List of Causes of Avoidable Deaths, 2008 Source: Adapted from the Brazilian List of Causes of Avoidable Deaths.

\section{Q RESULTS}

In Rondônia, of the 297,651 records of live births,4,374 (1.46\%) of newborns died in the neonatal and post-neonatal period. Of this total, $0.09 \%$ of the records were excluded due to the absence of the underlying cause of death, and $0.73 \%$ were classified as stillborn. Table 1 shows the general infant mortality rate in Rondônia, considering to preventable and non-preventable causes during the studied period. Of the 4,338 deaths, $62.70 \%$ were due to preventable causes. The average infant mortality rate from 2008 to 2018 was 14.57 deaths per thousand live births, with the average rate of deaths from preventable causes being 9.14/1,000 LB.

As for the infant death trend, there is an annual reduction of $2.88 \%$ in general deaths and $4.71 \%$ in those due to preventable causes. However, deaths from non-preventable causes remained stable annually (0.95\%).

Almost half of preventable deaths were due to causes that could be prevented through adequate care for the newborn (48.08\%), followed by preventable causes by appropriate prevention, diagnosis and treatment actions (15.60\%), and adequate care for women during childbirth (13.67\%). Table 2 
Freitas JLG, Alves JC, Pereira PPS, Moreira KFA, Farias ES, Cavalcante DFB

Table 1 - Infant mortality rate and trend by general type, preventable and non-preventable causes, Rondônia, Brazil, 2008 to $2018(n=4,338)$

\begin{tabular}{cccc} 
Year & Death rate & $\begin{array}{c}\text { Rate of preventable } \\
\text { causes }\end{array}$ & $\begin{array}{c}\text { Rate of non-preventable } \\
\text { causes }\end{array}$ \\
2008 & 16.12 & 10.68 & 5.45 \\
2009 & 17.44 & 11.73 & 5.71 \\
2010 & 18.54 & 12.15 & 6.39 \\
2011 & 13.31 & 8.57 & 4.74 \\
2012 & 13.73 & 8.86 & 4.87 \\
2013 & 13.91 & 8.64 & 5.28 \\
2014 & 14.37 & 9.33 & 5.04 \\
2015 & 14.47 & 9.13 & 8.92 \\
2016 & 13.42 & 7.26 & 6.16 \\
2017 & 12.80 & 7.56 & 5.24 \\
2018 & 12.60 & 6.94 & 5.66 \\
$r^{2}$ & & & \\
$b^{*}($ IC95\%) & 0.62 & 0.75 & 0.04 \\
Peath & $-2.88(-4.67 ;-1.06)$ & $-4.71(-6.55 ;-2.83)$ & $0.95(-2.87 ; 4.93)$ \\
Trend & $<0.01$ & $<0.01$ & 0.59 \\
\hline
\end{tabular}

Source: Deaths Mortality Information System (SIM).

${ }^{*}$ Applied to the APC formula (Annual Percent Change) $=[-1+10 \mathrm{~b} 1]^{*} 100 \%$ and $95 \% \mathrm{Cl}=[-1+10 \mathrm{~b} 1 \mathrm{~min} .]^{*} 100 \% ;[-1+10 \mathrm{~b} 1 \mathrm{max} .]^{*} 100 \%$.

Table 2 - Trend of infant death by group of preventable causes, Rondônia, Brazil, 2008-2018 ( $n=2,720)$

\begin{tabular}{|c|c|c|c|c|}
\hline $\begin{array}{l}\text { Group of Causes reducible by } \\
\text { appropriate actions }\end{array}$ & $\mathbf{r}^{2}$ & b* (IC95\%) & $\mathbf{p}$ & Trend \\
\hline 1. Immunization and sensitive conditions & 0.87 & $-3.30(-19.09 ; 15.55)$ & 0.59 & Stationary \\
\hline $\begin{array}{l}\text { 2. For women during pregnancy and } \\
\text { fetal growth }\end{array}$ & 0.21 & $-6.38(-14.88 ; 2.97)$ & 0.15 & Stationary \\
\hline 3. For women in childbirth & 0.33 & $-5.29(-10.57 ; 0.30)$ & 0.06 & Stationary \\
\hline 4. For newborns & 0.61 & $-5.08(-8.24 ;-1.81)$ & $<0.01$ & Descending \\
\hline 5. Prevention, diagnosis and early treatment & 0.50 & $-4.09(-6.88 ;-1.21)$ & 0.01 & Descending \\
\hline 6. Health Care and Promotion & 0.67 & $-5.44(-8.27 ;-2.53)$ & $<0.01$ & Descending \\
\hline
\end{tabular}

Source: Deaths Mortality Information System (SIM).

*Applied to the APC formula (Annual Percent Change) $=[-1+10 \mathrm{~b} 1]{ }^{*} 100 \%$ and $95 \% \mathrm{Cl}=[-1+10 \mathrm{~b} 1 \mathrm{~min} .]^{*} 100 \% ;[-1+10 \mathrm{~b} 1 \mathrm{max} .]^{*} 100 \%$.

shows the trend analysis of the historical series of deaths by group of preventable causes in the years analyzed. Among the causes that can be reduced by appropriate actions for the newborn, prevention, early diagnosis and treatment and Health Care and Promotion, had a decreasing trend. The remaining three causes remained stable. 
Table 3 shows the trend of infant deaths in the early, late and post-neonatal components. Of the 4,338 deaths, almost half (48.87\%) occurred in the early neonatal period and, in this period, the annual trend remained stable. Only preventable causes in the late period tended to decline $(-11.69 ; 95 \% \mathrm{Cl}:-19,56 ;-3.05)$.

Table 3 - Infant death trend due to early, late and post-neonatal period, resulting from preventable and non-preventable causes, Rondônia, Brazil, 2008-2018 ( $n=4,338)$
Cause
$r^{2}$
b*
P
Trend

\section{Early neonatal $(n=2,191)$}

Preventable

Not preventable
0.61

0.99
$-2.45(-5.24 ; 0.42)$

$-1.28(-5.72 ; 3.36)$
$0.08 \quad$ Stable

0.54 Stable

\section{Late neonatal $(n=2,100)$}

Preventable

Not preventable
0.48

0.41

$$
\begin{gathered}
-11.69(-19.56 ;-3.05) \\
1.08(-1.50 ; 3.74)
\end{gathered}
$$

0.01

0.37

Decline

Stable

\section{Post-neonatal $(n=47)$}

Preventable

Not preventable*
0.72

$-5.97(-12.14 ; 0.63)$

0.07

Stable

Source: Deaths Mortality Information System (SIM).

${ }^{*}$ Applied to the APC formula (Annual Percent Change) $=[-1+10 \mathrm{~b} 1]^{*} 100 \%$ and $95 \% \mathrm{Cl}=[-1+10 \mathrm{~b} 1 \mathrm{~min} .]^{*} 100 \% ;[-1+10 \mathrm{~b} 1 \mathrm{max} .]^{*} 100 \%$

** Only 2008 had deaths.

\section{DISCUSSION}

In the state of Rondônia, infant mortality from preventable causes was prevalent in the group of conditions that require adequate attention to the newborn, and by appropriate prevention, diagnosis and early treatment actions. The mean IMR for preventable causes in the period was 9.14/1,000 LB, with a gradual and slow reduction over the analyzed years.

Studies on preventable infant death in the capital of Porto Velho, Rondônia, between 2011 and 2015 identified that $48.08 \%$ of deaths were due to causes that could be reduced by implementing adequate care for the newborn, appropriate prevention, diagnosis and treatment actions (15.60\%) and adequate care for women during pregnancy (13.16\%) and childbirth (13.36\%) ${ }^{(12)}$.

In Aracaju, the capital of Sergipe, in the northeast of the country, an analysis of the IM rate in preventable causes, between 2007 and 2015(8), highlighted results similar to those found in Rondônia in the period from 2008 to 2018, where the main causes of infant deaths were also related to the attention given to women during pregnancy (46\%), followed by attention given to the newborn (23\%), and attention given to women during childbirth (18.4\%).

In this study, the decline in the total mortality rate is consistent with analyzes carried out in different periods and regions of the country between 2000 and $2013^{(17)}$, which showed an annual decline of $5.1 \%$ in IMR resulting from preventable causes in children from zero to four years of age.

The decrease in the rate is attributed to the improvement of this sensitive public health indicator and the adoption of sanitary measures in recent years, which resulted in the reduction of diseases prevalent in childhood. However, in the state of Rondônia, when assessed by period (exception to late neonatal due to non-preventable causes) and by type of preventable causes (three out of six causes), it remains stable. Other less disadvantaged regions of Brazil also showed partial improvements in assistance to mothers and newborns ${ }^{(2,10,17)}$.

Worldwide, investments to improve the indicators of infant mortality should meet the millennium goal to reduce neonatal mortality to $12 / 1,000$ live births by $2030^{(3-4)}$. In Brazil, changes in IM due to preventable causes, for example, have occurred even in less developed regions of northeastern Brazil, with a significant decrease in IMR to 10.4/1,000 LB, a decrease of $12.3 \%$ in eight years (2007 to 2007). 2015) in the analyzed period ${ }^{(8)}$.

On the other hand, although with regional differences, IMR due to preventable causes reflect failures in health care and are events that should not occur, especially due to improvements in available technologies. Studies in more developed regions, such as Espírito Santo, southeastern Brazil, 
analyzes of 4,805 infant deaths from preventable causes from 2006 to 2013, represented $77.2 \%$ of the records, with a reduction from $28.7 \%$ to $22.9 \%$ in the years analyzed ${ }^{(6)}$. According to authors, this reduction occurred, mainly due to the gradual improvement in socioeconomic indicators and the timely interventions by health services in the region.

The decline in total IMT in Rondônia was lower in relation to rates in other Brazilian regions ${ }^{(6,9-10)}$, and in other countries with similar levels of development to $\mathrm{Brazi}^{(3)}$ in the same period analyzed. The mean IMR in the state $(14.57 / 1,000$ LB) was higher than the national average $(12.4 / 1,000 \mathrm{LB})$ in the same period ${ }^{(5)}$, but lower when compared to the North region (17.6/1,000 LB) ${ }^{(10)}$. In Brazil, in 2019, of the 23,282 preventable infant deaths, $13.25 \%$ occurred in the North and $0.85 \%$ in the state of Rondônia(9).

Two studies on IMR in the capital of Rondônia registered a reduction in the Early Neonatal Mortality Rate from 12.7 to 12.5/1,000 LB between 2006 to $2010^{(11)}$ and 7.26 to 6.88/1,000 LB between 2011 to $2015^{(12)}$. However, in the period from 2008 to 2018, the reduction in IMR in the early neonatal period remained stable. Despite the financial incentives of SUS, such as the expansion of the FHS in the region ${ }^{(18)} \mathrm{com}$ bined with the qualification of state and municipal health managers, these investments were not sufficient to reduce the occurrence of deaths in the early neonatal period. The improvement of this indicator will occur with the strengthening of assistance to the mother-child binomial, mainly due to the increase and qualification of the coverage of the Family Health Strategy ${ }^{(19)}$. It is important to emphasize that the persistence of socioeconomic inequalities also influences the context of this investigation ${ }^{(9-10)}$.

Rondônia presented a stable annual trend for deaths preventable by immunization actions, care for women during pregnancy and childbirth. This stability points to the need for improvements in access to information as well as prenatal, childbirth and puerperium services, assistance to newborns ${ }^{(2,8)}$. Elevated IMR in the neonatal component due to preventable causes, are related to the conditions of the gestational period and childbirth with early neonatal deaths ${ }^{(6,20)}$.

It is a consensus that adequate care for women in prenatal care, childbirth and the puerperium, promoted by the health services that integrate the line of care, are strategies to reduce infant deaths. In this sense, it is necessary to improve the quality of care in the prevention, diagnosis and early treatment of infections in prenatal care, childbirth and birth, especially in the first six days of life. Furthermore, municipal management committed to child health care is crucial for reducing neonatal mortality ${ }^{(10,17)}$.

Although the results of this analysis corroborate with other studies, its limitations are highlighted by the use of secondary databases, subject to incomplete/incorrect filling in of variables obtained from the death certificates of SINASC and SIM. On the other hand, they are more accessible and comprehensive sources, with considerable sample size and, therefore, allow the extrapolation of the aspects analyzed for purposes of comparison with other regions.

The results of the study are unprecedented for the state, as it expands studies that were restricted to the capital until then, and will subsidize monitoring of IMR in the 52 municipalities, in line with the guidelines of the National Policy for Comprehensive Child Health Care (PNAISC) within the scope of SUS ${ }^{(15)}$. In this sense, the study may serve as a basis for further research in response to the problem of IMR, to be applied in the academy, integrating teaching-service-community, through the interprofessional practices of homes in the region's health care network.

\section{CONCLUSIONS}

In Rondônia, infant mortality due to preventable causes was associated with actions that require adequate attention to the newborn, with appropriate actions for prevention, diagnosis and early treatment and care for women during childbirth. There are serious flaws and gaps in the line of maternal and child care, possibly related to prenatal care, childbirth and birth, especially in the first six days of life.

Infant deaths due to preventable causes, especially in the early neonatal period, decreased in the last two years evaluated, in contrast to the stationary trend of non-preventable deaths, which shows possible neglect of other diseases.

It is urgent that municipal managers invest in the qualification of assistance to the mother-child binomial, especially in Primary Health Care, valuing the performance of the team of professionals who work throughout the postpartum pregnancy cycle, as well as training doctors to improve the quality of the indicator records of infant mortality in the region.

\section{$\square$ REFERENCES}

1. Oliveira ISS, Torres RS, Rocha FC, FerreiraTN. Preventable deaths in children under five in the Macro Norte region of the state of Minas Gerais, Brazil. Rev Bioét. 2018;26(3):397-402. doi: https://doi.org/10.1590/1983-80422018263259

2. Maia LTS, Souza WV, Mendes, ACG. Determinantes individuais e contextuais associados à mortalidade infantil nas capitais brasileiras: uma abordagem multinível. Cad Saúde Pública 2020;36(2):e00057519. doi: https://doi. org/10.1590/0102-311x00057519

3. United Nations Children's Fund (US). Levels \& trends in child mortality: report 2020: estimates developed by the UN Inter-agency Group for Child Mortality Estimation. New York: UNICEF; c2020 [cited 2020 Sep 30]. Available from: https:// data.unicef.org/resources/levels-and-trends-in-child-mortality/ 
4. GBD 2016 Causes of Death Collaborators. Global, regional, and national age-sex specific mortality for 264 causes of death, 1980-2016: a systematic analysis for the Global Burden of Disease Study 2016. Lancet. 2017;390(10106):1151-210. doi: https://doi.org/10.1016/S0140-6736(17)32152-9

5. Instituto Brasileiro de Geografia e Estatística [Internet]. Rio de Janeiro: IBGE; c2020- [cited 2020 May 27]. Taxa de mortalidade infantil por mil nascidos vivos - Brasil 2000 a 2015; [about 1 screen]. Available from: https://brasilemsintese. ibge.gov.br/populacao/taxas-de-mortalidade-infantil.html

6. Dias BAS, Santos Neto ET, Andrade MAC, Zandonade E. Spatial analysis of avoidable infant deaths in Espírito Santo, Brazil, 2006-2013. Epidemiol Serv Saúde. 2019;28(3):e2018111. doi: https://doi.org/10.5123/s1679-49742019000300001

7. Dias BAS, Santos Neto ET, Andrade MAC. Classification systems for avoidability of infant deaths: different methods, different repercussions? Cad Saúde Pública. 2017;33(5):e00125916. doi: https://doi.org/10.1590/0102-311×00125916

8. Lemos ACS, Rocha AA. Análise da mortalidade infantil por causas evitáveis no município de Aracaju-SE de 2007 a 2015. C\&D Rev Eletrôn FAINOR. 2018;11(2):371-84.

9. Ministério da Saúde (BR). Secretaria de Vigilância em Saúde. Departamento de Análise de Saúde e Vigilância de Doenças Não Transmissíveis. Brasília, DF; c2020 [cited 2020 May 30]. Painel de monitoramento de mortalidade infantil e fetal; [about 1 screen]. Available from: http://svs.aids.gov.br/dantps/ centrais-de-conteudos/paineis-de-monitoramento/mortalidade/infantil-e-fetal/

10. Caldas ADR, Santos RV, Borges GM, Valente JG, Portela MC, Marinho GL. Mortalidade infantil segundo cor ou raça com base no Censo Demográfico de 2010 e nos sistemas nacionais de informação em saúde no Brasil. Cad Saúde Pública. 2017;33(7):e00046516. doi: https://doi.org/10.1590/0102-311×00046516

11. Moreira KFA, Oliveira TS, Gonçalves TA, Moura CO, MalufSN, Tavares RSA, et al. Child Mortality in the Last Five-Year Periods in the City of Porto Velho, R0, Brazil. Rev Bras Crescim Desenvolv Hum. 2014 [cited 2020 May19];24(1):86-92. Available from: http://pepsic.bvsalud.org/pdf/rbcdh/v24n1/13.pdf

12. Moreira KFA, Bicalho BO, Santos LCS, Amaral FMGS, Orfão NH, Cunha MPL. Profile and preventability of neonatal death in a city in Legal Amazon. Cogitare Enferm. 2017;22(2):e48950. doi: https://doi.org/10.5380/ce.v22i2.48950

\section{- Authorship contribution:}

Conceptualization, Administration and supervision of the project and Methodology: Jeanne Lúcia Gadelha Freitas.

Investigation and original writing: Jéssica Cunha Alves.

Formal analysis and Writing - revision and editing:

Priscilla Perez da Silva Pereira.

Methodology: Kátia Fernanda Alves Moreira.

Methodology and Formal Analysis: Edson dos Santos

Farias.

Investigation and Writing - revision and editing:

Daniela Ferreira Borba Cavalcante.

\section{- Corresponding author:}

Jeanne Lúcia Gadelha Freitas.

E-mail: jeannegadelha@unir.br

Received: 07.18.2020

Approved: 11.12 .2020
13. Ministério da Saúde (BR). Rede Interagencial de Informações para a Saúde-RIPSA [Internet]. Brasília, DF; c2020- [cited 2020 May 27]. Indicadores demográficos [about 1 screen]. Available from: http://tabnet.datasus.gov.br/cgi/tabcgi. exe?idb2012/a09.def

14. Barbosa, SFAB, Costa FM, Vieira MA. Causas de hospitalização de crianças: uma revisão integrativa da realidade brasileira. Espaço Saúde. 2017 [cited 2020 May 27];18(2):129-37. Available from: http://espacoparasaude.fpp.edu.br/index. php/espacosaude/article/view/245/pdf_1

15. Ministério da Saúde (BR). Portaria № 1.130, de 5 de agosto de 2015. Institui a Política Nacional de Atenção Integral à Saúde da Criança (PNAISC) no âmbito do Sistema Único de Saúde (SUS). Diário Oficial da União. 2015 ago 06 [cited 2020 May 27];152(149Seçãol):37-9. Availablefrom: https://pesquisa.in.gov.br/imprensa/jsp/ visualiza/index.jsp?data $=06 / 08 / 2015 \&$ jornal $=1 \&$ pagina $=37 \&$ totalArquivos $=76$

16. Instituto Brasileiro de Geografia e Estatística [Internet]. Rio de Janeiro: IBGE; c2010- [cited 2019 Jul 17]. Rondônia: panorama; [about 1 screen]. Available from: https://cidades.ibge.gov.br/brasil/ro/panorama

17. Malta DC, Prado RR, Saltarelli RMF, Monteiro RA, Souza MFM, Almeida MF. Preventable deaths in childhood, according to actions of the Unified Health System, Brazil. Rev Bras Epidemiol. 2019;22:e190014. doi: https://doi. org/10.1590/1980-549720190014

18. Ministério da Saúde (BR), Conselho Nacional de Saúde. Resolução nº 466, de 12 de dezembro de 2012. Diretrizes e normas regulamentadoras de pesquisas envolvendo seres humanos. Diário Oficial da União. 2013 jun 13 [cited 2020 May 27];150(112 Seção 1):59-62. Available from: https://pesquisa.in.gov.br/imprensa/jsp/visualiza/ index.jsp?data $=13 / 06 / 2013 \&$ jornal $=1 \&$ pagina $=59 \&$ total Arquivos $=140$

19. Santos BV, Lima DS, Fontes CJF. Hospitalization for ambulatory care-sensitive conditions in the state of Rondônia, Brazil: a descriptive study of the period 2012-2016. Epidemiol Serv Saúde. 2019;28(1):e2017497. doi: https://doi. org/10.5123/s1679-49742019000100001

20. Demitto MO, Gravena AAF, Dell'Agnolo CM, Antunes MB, Pelloso SM. High risk pregnancies and factors associated with neonatal death. Rev Esc Enferm USP. 2017;51:e03208. doi: https://doi.org/10.1590/s1980-220x2016127103208

\section{Associate editor:}

Jéssica Machado Teles

Editor-in-chief:

Maria da Graça Oliveira Crossetti 